\title{
New therapeutic targets in ovarian cancer stem cells
}

\author{
Livia Elena Sima ${ }^{1}$, Salvatore Condello $^{1}$, Daniela Elena Matei ${ }^{1,2,3 *}$ \\ ${ }^{1}$ Division of Reproductive Science and Medicine, Department of Obstetrics and Gynecology, \\ Northwestern University Feinberg School of Medicine, Chicago, Illinois, 60611, US \\ ${ }^{2}$ Robert H. Lurie Comprehensive Cancer Center, Chicago, IL, US \\ ${ }^{3}$ Jesse Brown VA Medical Center, Chicago, IL, US
}

(Received 27 March 2017; accepted 18 May, 2017)

\begin{abstract}
Ovarian cancer (OC) is the deadliest gynecological malignancy. Characterized by frequent recurrences after standard chemotherapy and a pattern of dissemination in the peritoneal cavity, ovarian tumor development and progression may be driven by cancer stem cells (CSCs). This concept is supported by the identification of a subset of OC cells with stem-like characteristics, including self-renewal, ability to differentiate and to initiate tumors in vivo. It has been proposed that ovarian CSCs are responsible for development of chemotherapy resistance and of disease recurrence, which occur commonly in OC. Several markers are used for the isolation of ovarian CSCs and distinct pathways fuel their survival and proliferation within the tumor microenvironment (TME). Here we aim to review recent advances in the field of ovarian CSCs and to discuss novel therapeutic targets which could be exploited to eliminate this tumor cell sub-population with the goal of preventing emergence of resistance to chemotherapy and disease progression.
\end{abstract}

Keywords: ovarian cancer, stem cells

\section{CANCER STEM CELLS - A PROVOCATIVE CONCEPT}

Whether classified as "tumor-initiating" cells, "cancer stem-like" cells or simply "cancer stem cells" (CSCs), this small population of highly undifferentiated and slow cycling cells is implicated in early molecular events linked to cancer development as well as in tumor progression, recurrence, and development of chemotherapy resistance (1). During the last decade an increasing amount of scientific reports yielded proof of existence of a subpopulation of cells within tumors bearing the main characteristics of stem cells in normal tissues: quiescence and capacity of self-renewal and differentiation (2). Specific signaling pathways controlling normal stem cells identity were found to regulate the phenotype of this subset of tumor cells bearing "stemness" features (3).

The first report documenting a cancer initiating cell phenotype in solid tumors was published in 2003 in a breast cancer model (4). CD $44^{\text {high }} / \mathrm{CD} 24^{\text {low }}$ cells are characterized by self-renewal properties, tumor initiating capacity in vivo, when injected in small numbers (50-100) in NOD/SCID mice, and ability to differentiate into cells with more specific phenotypes and functions. Since that report, the field expanded to include most solid tumors, continuously refining the cancer stem cell hypothesis. However, the very existence of CSCs remains controversial, as researchers have struggled to define similarities and distinct traits between normal and cancer stem cells (5). Although CSCs were described by Hans Clevers as "malignant equivalents of tissue stem cells" (6), it remains open for debate whether cancer occurs by mutations in normal tissue-specific stem cells or whether transformation follows in transit amplifying cells or even in more committed cells driving their dedifferentiation to stem-like cancer cells $(7,8)$.

It is accepted that CSCs represent a rare cell population within tumors, however their precise quantification has been variable. The most extreme report comes from the melanoma models, suggesting that CSCs can recapitulate

*Contact information (Diana Princess of Wales Professor in Cancer Research, Northwestern University Feinberg School of Medicine, 303 E. Superior Street, Lurie Cancer Center L4-107, Chicago, IL, USA

E-mail: daniela.matei@northwestern.edu) 
a heterogeneous tumor from a single cell (9). Data obtained by injecting mouse lymphoma or leukemia cells into histocompatible mice has challenged the concept of rare quiescent cells driving cancer by showing that at least $10 \%$ of these cells can sustain tumor growth (10). Other studies have reported that this fraction ranges between "0.6\%-50\%", depending on the animal model and tissue type (11). This partially accepted paradigm has fueled research endeavors in most solid tumors, including ovarian cancer [reviewed in $(12,13)]$. In this review we will focus on the specific traits associated with ovarian cancer stem cells (OCSCs) and their potential therapeutic targeting using various modalities - ranging from agents directed towards stem cell markers or blocking specific stem related pathways to the use of inhibitors of general oncogenic processes or metabolic pathways fueling tumor growth and metastasis, which also affect CSCs.

\section{OVARIAN CANCER BIOLOGY}

Ovarian cancer (OC) accounts for approximately three percent of cancers in women according to the Ovarian Cancer Research Fund Alliance (14). The lifetime risk of developing OC is 1 in 75 with the highest rates occurring in women aged 55-64 years. The 5-year overall survival is $-46 \%$, rendering OC the deadliest of gynecologic malignancies. Epithelial ovarian carcinomas (representing $80 \%$ of ovarian tumors) are classified in four histological subtypes: i) serous/serous-papillary, which is the most common subtype; ii) endometrioid; iii) mucinous; and iv) clear-cell carcinoma (15). Gene expression profiles vary by histological subtype reflecting distinct origin (16). Molecularly, high grade serous ovarian cancer is characterized by a TP53 mutated signature and deficiency in DNA repair signature, as demonstrated by analyses in the human Cancer Genome Atlas (17).

The cell of origin has been a topic of controversy in the field. Initially, it was thought that OC originates in the surface epithelium of the ovary. The ovarian epithelium is endowed with regenerative capacity given by resident somatic stem cells, which were identified in mouse as label-retaining cells, mitotically responsive to ovulation (18). Gene expression profiling analyses were conducted on ovarian surface epithelia (OSE) samples collected in vivo and laser capture microdissected cancer epithelia (CEPI) from serous papillary ovarian adenocarcinomas collected from flash frozen tissue. The results clearly indicated an enrichment in genes associated with adult stem cell maintenance in OSE compared to CEPI. While neoplastic transformation of uncommitted multipotent progenitor cells can confine the origin of OCSCs to ovarian surface epithelia, these results may not rule out the possibility that OC arises from other sources (19). More recently, it has been proposed that $\mathrm{OC}$ originates from the epithelium of the fallopian fimbriae. OC resembles the cellular and molecular characteristics of the fallopian tube epithelium, which is embryologically derived from the müllerian duct (20). Furthermore, serous tubal intraepithelial carcinomas (STIC) lesions have been described in carriers of BRCA1 and 2 mutations and proposed to represent precursor cancer lesions $(21,22)$. New data point to the mesothelium-lined peritoneal cavity (15) as a potential origin of a subgroup of ovarian tumors. A recent report using integrative whole-exome sequencing and phylogenetic analyses of genomic mutations of primary tumors, STIC lesions, and metastatic implants (23) identified diverse metastatic trajectories among the cases studied. The core mutation identified in all samples as primary driver of cell transformation was TP53. From that first molecular event, three distinct routes of dissemination were characterized: first, coined "basal STIC", in which STIC represents the initiating event; second, termed "parallel" dissemination, in which all branches developed independently from the same precursor; and the third, named "STIC metastasis", in which the STIC lesions appears to be a metastatic deposits originating from a primary peritoneal site. The latter was an unexpected discovery, as there was no previous evidence of OC cells metastatic to the fallopian tube. This latter theory is supported by evidence from other models. For example, the linear stepwise model of cancer progression from primary lesion to metastatic implants, with constant accumulation of genetic mutations, has been challenged by the discovery of parallel progression pathways in breast cancer models $(24,25)$. It appears that not all cells populating metastatic sites are derived from the primary tumor. That there are cells that leave the primary site very early during progression and evolve independently of those metastasizing at later time points, with more aggressive behavior (26).

\section{OVARIAN CANCER STEM CELLS}

A PubMed search of all published articles on ovarian cancer stem/initiating cells was performed using the following terms: "ovarian cancer" and "cancer stem cells" or "OC" and "initiating cells", or "OC stem cells" or "OC stem-like" or "side-population ovarian cells". Our research retrieved 234 publications out of which 227 were direct studies of OCSCs, with the first being published in 2006. Of those, 194 are original reports, while 33 are reviews (Fig. 1). The first report of cells with tumor initiating capacity in OC identified the "side population" (SP) consisting of cells able to exclude the Hoechst dye as those cells able to generate tumors when injected in small numbers in nude mice (27). Subsequently, several cell surface markers (such as CD133, CD44, CD117) have been proposed for the isolation of OCSCs from primary tumors or cell lines (see Table 1). Other intracellular markers, such as MyD88 or aldehyde dehydrogenase $(\mathrm{ALDH})$ activity have also been recognized as potential 
Table 1. Proposed markers that define OCSC tumor subset (from the latest to the first study)

OCSC specific marker

\section{Functional markers}

\begin{tabular}{|c|c|c|}
\hline SP & Hoechst efflux & $(27,98-100)$ \\
\hline ABCG2+ SP cells & Drug efflux pump & $(44,101)$ \\
\hline $\begin{array}{l}\text { SP as heterogenous CSC } \\
\text { compartment }\end{array}$ & Hoechst efflux & $(102)$ \\
\hline ALDH1 & Enzyme & $(103-105)$ \\
\hline \multicolumn{3}{|c|}{ Membrane receptors } \\
\hline CD133+ & Pentaspan transmembrane glycoprotein localized to cell protrusions & $(106)$ \\
\hline $\mathrm{CD} 24$ & Cell adhesion glycoprotein & $(84)$ \\
\hline CD44v6 & Splicing variant 6 of CD44 & $(107)$ \\
\hline E-cadherin (CD324) & Cell-cell adhesion molecule & $(108)$ \\
\hline ROR1 & Receptor & $(109)$ \\
\hline (mem)GRP78 & Chaperone protein & $(110)$ \\
\hline $\begin{array}{l}\text { CD44+ } \\
\text { CD117+ }\end{array}$ & $\begin{array}{l}\text { Cell-cell adhesion glycoprotein } \\
\text { Receptor tyrosine kinase protein }\end{array}$ & $(111)$ \\
\hline $\begin{array}{l}\text { CD } 44+ \\
\text { CD133+ }\end{array}$ & & $(112)$ \\
\hline $\begin{array}{l}\text { CD44+ } \\
\text { CK19+ }\end{array}$ & $\begin{array}{l}\text { Cell-cell adhesion glycoprotein } \\
\text { Cytokeratin present in carcinomas and glandular-type epithelia }\end{array}$ & $(113)$ \\
\hline $\begin{array}{l}\text { CD133+ } \\
\mathrm{AR}+\end{array}$ & Nuclear androgen receptor & $(114)$ \\
\hline $\begin{array}{l}\text { CA125+ } \\
\text { lineage- }\end{array}$ & $\begin{array}{l}\text { Member of the mucin family glycoproteins } \\
\text { Hematopoietic stem cell marker }\end{array}$ & $(115)$ \\
\hline $\begin{array}{l}\text { CD44low } \\
\text { CD24+ } \\
\text { CD117+ } \\
\text { VEGF-R+ }\end{array}$ & Receptor for angiogenic protein VEGF & $(116)$ \\
\hline \multicolumn{3}{|c|}{ Intracellular markers } \\
\hline miR-551b & micro RNA & $(117)$ \\
\hline DDX4 & RNA helicase & $(118)$ \\
\hline \multicolumn{3}{|c|}{ Combinations of membrane, intracellular and functional markers } \\
\hline $\begin{array}{l}\text { CD } 44+ \\
\text { MyD88+ } \\
\text { constitutive NF- } \kappa B \text { activity }\end{array}$ & $\begin{array}{l}\text { Adaptor molecule for Ras transformation } \\
\text { Cell transduction }\end{array}$ & $(119)$ \\
\hline $\begin{array}{l}\mathrm{ALDH}+ \\
\mathrm{CD} 133+\end{array}$ & & $\begin{array}{l}(28,120, \\
121)\end{array}$ \\
\hline $\begin{array}{l}\text { SP } \\
\text { ALDHbright } \\
\text { Sox2 as functional marker }\end{array}$ & Stemness transcription factor & $(122)$ \\
\hline $\begin{array}{l}\text { Thymosin beta } 4 \\
\text { CD133 }\end{array}$ & Small protein involved in tissue regeneration & $(123)$ \\
\hline \multicolumn{3}{|c|}{ Biophysical traits } \\
\hline $\begin{array}{l}\text { Small stem cells with diameters of } \\
\text { up to } 5 \mu \mathrm{m} \text { in borderline ovarian } \\
\text { cancer tumors }\end{array}$ & Cell size & $(124)$ \\
\hline \multicolumn{3}{|c|}{ Metabolic markers } \\
\hline Unsaturated lipids & Lipid metabolism components & $(64)$ \\
\hline
\end{tabular}

Abbreviations: SP=side-population; ABCG2=ATP Binding Cassette Subfamily G Member 2; ALDH1=aldehyde dehydrogenase 1; ROR1=type I receptor tyrosine kinase-like orphan receptor; memGRP78=membrane Glucose Regulated Protein 78; AR=androgen receptor; VEGF-R=Vascular Endothelial Growth Factor Receptor; DDX4=DEADboxpolypeptide4;MyD88=Myeloiddifferentiation primary responsegene 88; NF- $\kappa \mathrm{B}=$ Nuclearfactor-kappaB; Sox2=SRY (sex determining region Y)-box 2 . 
markers of stemness. A robust phenotype validated by several groups is characterized by co-expression of $\mathrm{ALDH}^{+} / \mathrm{CD} 133^{+}$(Fig. 2) (28).

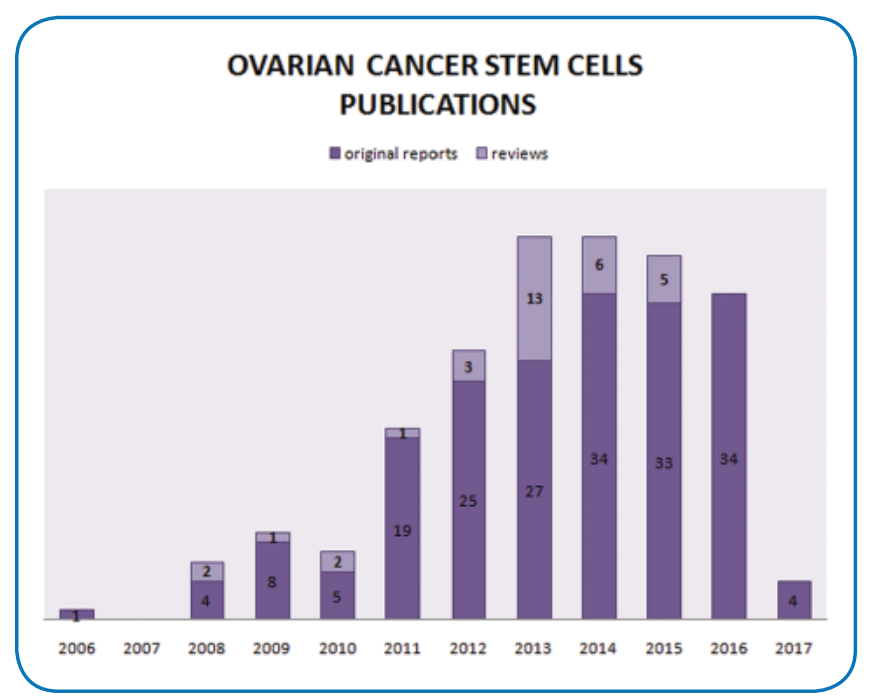

Fig. 1. - Graph depicting the dynamics of articles published on OCSC topic in the last decade

The heterogeneity of OCSCs became apparent immediately after the first few reports proposed the existence of this subpopulation $(29,30)$. It has been suggested that in fact the OCSC population may be composed of subsets of cells characterized by different and distinct markers (31). This view is supported by a study revealing a heterogenic portrait of OC tumors featuring clonal diversity and tumor front OCSCs with various properties, such as SP phenotype, $\mathrm{CD} 24^{+}$and $\mathrm{CD} 117^{+}$expression (29). Also, it is possible that the OCSC frequency varies between tumors. Interestingly, similar percentages of OCSCs were observed in primary ovarian masses and in omental metastases, suggesting that the fraction of OCSCs is an intrinsic property preserved during cancer progression (30).

Moreover, OCSCs are enriched by culture as spheroids under non adherent conditions and in the absence of serum to prevent cellular differentiation (32). During cancer progression, cells modify their cytoskeleton to be able to adapt to new tissue environments. Atomic force microscopy measurements have provided evidence of the "softness" of OCSC as compared to normal ovarian epithelial cells as well as to transformed cells (33). However, when analyzing cancer cell- or patient-derived spheroids, more compact spheres proved to be more invasive than $3 \mathrm{D}$ structures with scattered cell distribution (34). Based on their differentiation ability, OC spheroids have been classified in two groups - one with multiple transdifferentiation potency (SR1) and one with a limited differentiation potential (SR2). The latter could derive from the former by epithelial to mesenchymal transformation (EMT), along with progressive loss of alkaline phosphatase activity, a known marker of (embryonic) stem cells (35). Another study claims that the initiating capacity of OC stem-like cells is an attribute of their mesenchymal phenotype (36). Although still controversial, this phenotypic transformation from epithelial to mesenchymal behavior could account for the cellular heterogeneity found in ovarian tumors, while contributing to the engraftment of metastatic cells (37). The possible relationship between OCSC and EMT is extensively discussed in Ref (38).

Increased $\mathrm{CD}_{4} 4^{+}$expressing OCSCs fraction was also found to correlate with recurrence in early stage ovarian cancers (39) and detection of SP cells in patient-derived specimens also correlated with increased risk of tumor

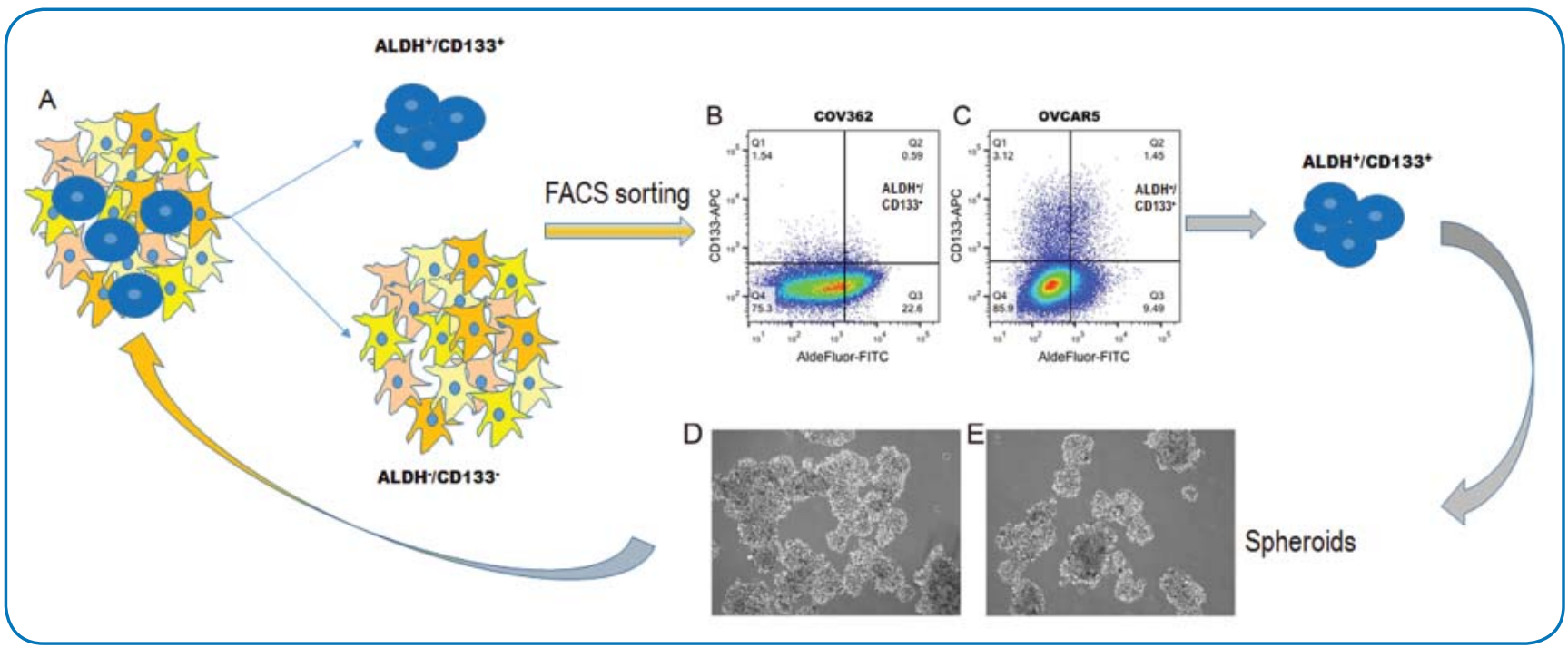

Fig. 2. - Isolation of OCSCs from OC cell lines. A) Cancer cells have a heterogeneous phenotype. OCSCs represent a cell subpopulation that can be identified by specific markers, such as ALDH activity and CD133 expression. B, C) By using fluorescent labeling and FACS sorting, putative OCSCs can be identified and separated from bulk tumor samples or cell lines, such as COV362 and OVCAR5. D, E) ALDH+/CD133+ cells can be grown in vitro in low attachment conditions. The formation of spheroids and recapitulation of tumor heterogeneity represents the validation of their CSC phenotype. 
recurrence (40). In addition, SP fraction was increased in paclitaxel-resistant OC cell lines (41). Doxorubicin, cisplatin, and paclitaxel were shown to enrich the tumor initiating cell fraction $(42,43)$. SP cells isolated from malignant ascites derived from $\mathrm{OC}$ patients and from mice inoculated with human $\mathrm{OC}$ cell lines were enriched in cancer stem cell markers ATP Binding Cassette Subfamily G Member 2 (ABCG2)/Breast cancer resistance protein 1 (BCRP1), Octamer-Binding Protein 4 (OCT4), STELLA-related (STELLAR), and homeobox transcription factor NANOG expression (44). These observations have driven researchers to infer that the stemlike subpopulations might be responsible for both tumor initiation, as well as for tumor recurrence and escape from chemotherapy, as OCSCs are progressively selected by serial cycles of treatment with cytotoxic agents, which are pumped out of these cells via ATP-binding cassette transporters.

The rare population of quiescent CSCs within tumors can be identified by the expression of distinct cell surface antigens (CD133, CD44, and CD117) and intracellular activity of detoxifying enzymes, such as aldehyde dehydrogenase 1 (ALDH1), as we show here (Fig. 2A). Thus, CSCs labeled with AldeFluor substrate, reflecting intracellular ALDH activity, and stained with specific antibodies directed against CD133, can be isolated by cell sorting (Fig. 2B - COV362 cells, Fig. 2C - OVCAR5 cells) and further characterized to assess self-renewal capacity, when cultured in ultra-low adherence conditions (Fig. 2D, E), and tumor initiating potential.

\section{SPECIFIC OCSC SIGNALING AND FUNCTIONS}

According to the cancer stem cell (CSC) hypothesis, a residual small population of cancer stem cells (less than $1 \%$ of the total population) which possess the capacity to undergo either symmetric or asymmetric division is responsible for recapitulating hierarchically organized human tumor phenotypes when injected in NOD/SCID mice (9). After the first reports on OCSCs have described putative markers of stem cells and their functional characteristics, more recent work focused on dissecting signaling pathways fueling stemness. Mechanisms found to be active and critical to OCSCs function are the Wnt/ $\beta$-catenin, JNK, NOTCH, and Hedgehog signaling pathways.

The current literature suggests that the tumor microenvironment (TME) consisting of different cell populations, including cancer activated fibroblasts (CAFs), adipocytes, immune and endothelial cells, exerts a primary role in protecting CSC from anoikis (45). Within the TME, different cell types define a specialized niche where a complex and dynamic tridimensional network of secreted extracellular matrix (ECM) macromolecules (fibronectin, collagen, laminin, proteoglycans) (46), mitogenic growth factors (vascular endothelial growth factor/VEGF, epidermal growth factor/EGF, and fibroblast growth factor/FGF), and cytokines (tumor necrosis factor $\alpha / T N F-\alpha$, and tumor growth factor $\beta /$ TGF- $\beta$ ) contributes to CSCs' survival and proliferation. The importance of the TME in regulating OC stemness has also been linked to hypoxia, one of the hallmarks of cancer, which substantially impacts tumor development and progression and influences survival of OCSCs (47). In growing tumors, where vascularization lags behind and causes hypoxic regions, upregulation of the c-kit receptor has been demonstrated. C-kit is a stem cell receptor that promotes OCSC growth and resistance to chemotherapy via activation of $\mathrm{Wnt} / \beta$-catenin pathway and ATP-binding cassette G2 (ABCG2) signaling (48). More recently, Wnt/ $\beta$-catenin signaling has also been shown to be a critical regulator of stem-like properties maintenance and drug resistance in platinum resistant HGSOC patient-derived xenograft (PDX) models (49). Within the TME, cancer-associated fibroblasts present within the tumor niche secrete FGF4 which stimulates OCSCs and increases their tumor initiation capacity (50). Moreover, OCSCs promote the M2 polarization of macrophages through the PPAR $\gamma / \mathrm{NF}-\kappa \mathrm{B}$ pathway (51), thus exerting pro-tumorigenic effects, by inhibiting T cells capacity to eliminate cancer cells.

Three-dimensional (3D) cell cultures have become a useful tool to closely study tumor characteristics and assess the TME's influence in regulating CSC survival and growth. When grown as spheroids in ultra-low adherence conditions, OCcells adopt a more mesenchymal phenotype which is linked to an enrichment in stem cell signaling. For example, OVCAR-3 cells grown as spheroids showed significant differences in TGF- $\beta$-dependent induction of EMT, regulation of lipid metabolism, NOTCH and Hedgehog signaling compared to the parental cells (32). Furthermore, TGF- $\beta$ stimulates proliferation of CSC enriched spheroids compared to the control treated cells (52), and genomic profiling identified Wnt/ $\beta$-catenin signaling as being upregulated and interconnected to TGF- $\beta$ and ALDH in OC spheroids compared with monolayer cultures (53). Additionally, it has been shown that TWIST-1 - a transcription factor that regulates gastrulation and mesoderm differentiation during embryonic development and is activated by TGF- $\beta$ signaling - is degraded in epithelial OCSCs while its over-expression correlates with differentiated epithelial cells (54). This mechanism could have implications for both the metastatic and chemoresistant phenotypes of cancer cells (55).

Elevated levels of gonadotropin hormones including the follicle-stimulating hormone (FSH) and FSH receptor (FSHR) expression in OC correlate with a poor prognosis, and are associated with increased mRNA expression level 
of several cancer stem cell markers (OCT4, LIN28 and BMP4) (56). Another stemness marker gene, Sox2, was found to be amplified in $26 \%$ of serous OCs (57) with negative impact on overall survival. The quest to better define OCSCs specific pathways continues, as more in-depth characterization of stemness mechanisms would enable the development of OCSC-targeted treatment to eliminate this cell population and prevent tumor relapse and metastasis.

\section{CANCER STEM CELL METABOLISM}

Metabolic adaptation during cancer progression enables tumor cells to survive in hypoxic environments and in the presence of noxious stimuli. For example, bioenergetic profiling of $\mathrm{CD} 44^{+} / \mathrm{MyD} 88^{+}$putative OCSCs revealed preferred use of glycolysis over oxidative phosphorylation to generate ATP (58), similarly to other multipotent stem cells $(59,60)$. Another study evaluating tumor initiating cells derived from mouse ovarian surface epithelial cells reported decrease in glucose and fatty acid oxidation with a concomitant increase in lactate production in this cell subset as compared with parental cells. At the same time, this cell population had an increased survival rate when treated with purine synthesis intermediate 5-Aminoimidazole-4-carboxamide ribonucleotide (AICAR), but exhibited higher sensitivity to the neo-glucogenesis inhibitor metformin, as compared to bulk cells. These results suggested that these metabolic traits could make OCSCs more adaptable to changes of the microenvironment (61).

Using two-dimensional gas chromatography coupled to mass spectrometry, Vermeersh KA et al. measured the metabolite profiles of OVCAR-3 spheroid-derived cells (enriched in OCSCs) as compared to those of more differentiated isogenic cancer cells and demonstrated other characteristics, such as enrichment of the arginine and proline metabolic pathway (62). Furthermore, using mass spectrometry-based metabolomics, the authors demonstrated that the metabolic responses of an ovarian cancer cells and OCSCs derived from this line differed greatly (63). Moreover, when challenged with the drug docetaxel, significant metabolic changes in amino acid and carbohydrate metabolism were evidenced in ovarian cancer cells, while no significant metabolic effect was found in OCSCs. Using a novel Raman spectroscopic molecular imaging method, our group reported significantly increased levels of unsaturated lipids in OCSCs as compared to non-CSCs (64). An increase in unsaturated lipid levels was also detected in spheroids compared to monolayer cultures derived from OC cell lines or from human OC specimens. Based on these findings, lipid unsaturation was proposed as a metabolic marker for OCSCs and as a target for CSC-specific therapy. Gene expression profiling correlated the CSC phenotype
$\left(\mathrm{ALDH}^{+} / \mathrm{CD} 133^{+}\right)$with the increase in lipid desaturases (SCD1) mRNA expression compared to non-CSC. As lipid $\beta$-oxidation is the most efficient energy generating pathway, it is possible that OCSCs take advantage of this source to survive and grow (65).

Interestingly, other recent reports proposed abnormal lipid metabolism in human oral carcinoma metastasis-initiating cells (66). These cells are characterized by increased expression of the fatty acid receptor CD36 and its inhibition was shown to impair metastasis also in melanoma and breast cancer models (67). Other reports support the importance of lipid metabolism for OCSCs and explain why OC cells metastasize with predilection to fat reach tissues, like the omentum. Adipocytes present in the OC microenvironment promote expression of anti-apoptotic proteins and confer chemoresistance of $\mathrm{CD} 44^{+} / \mathrm{MyD} 88^{+} \mathrm{OC}$ cells (68). Pro-inflammatory signals released in this environment - such as interleukin 6 (Il-6) - causes an increase of Bclxl, which inhibits apoptosis and enables cancer cells to survive effects of cytotoxic treatment. In another report, OCSCs isolated from spheroids were maintained through stimulation by lysophosphatidic acid (LPA), which was secreted and regulated by autotaxin enriched in CSCs (69). Increased levels of LPA were detected in media secreted by OCSCs as compared with non-CSCs media. Decreased survival was reported in patients whose tumors overexpressed autotaxin, an LPA-producing enzyme. Hence, the autotaxin-LPA-LPA receptor 1-AKT1 autocrine loop was proposed as another pathway potentially involved in OCSC survival.

\section{DEFINING SPECIFIC THERAPEUTIC TARGETS IN OCSCS}

Although efforts to eliminate CSCs have been ongoing for years, CSCs have remained moving targets given their rarity and plasticity (70). It is now accepted that chemotherapy is effective in eliminating heterogeneous tumor cell populations, but leaves behind CSCs, which are endowed with drug efflux mechanisms and are generally quiescent (Fig. 3), thus being able to escape the effects of cytotoxic drugs. In OC, despite initial response rates $>75 \%$ (71), resistance often emerges after the first-line treatment with platinum (cisplatin, carboplatin) or taxanes (paclitaxel) compounds and only $30 \%$ of patients diagnosed with advanced disease survive beyond 5 years (72). This has been attributed partly to persistence of OCSCs at the end of primary treatment. The plasticity of OCSC allows them to survive and to be enriched during disease progression as well as after chemotherapy. For example, studies using paclitaxel and carboplatin to treat ovarian xenograft bearing mice showed the persistence of OCSCs fraction following treatment along with the concomitant acquisition of 
Table 2. Targeted therapeutics for the elimination of OCSC

\begin{tabular}{|c|c|c|c|}
\hline Proposed therapeutic agent & Target & Target molecular class & Refs \\
\hline \multicolumn{4}{|l|}{ Epigenetic modulators } \\
\hline SGI-110 & DNA methylation level & $\begin{array}{l}\text { Epigenetic regulation of gene } \\
\text { expression }\end{array}$ & (79) \\
\hline GSKJ4 & $\begin{array}{l}\text { Jumonji H3K27 } \\
\text { Demethylase }\end{array}$ & $\begin{array}{l}\text { Epigenetic modifier - histone } \\
\text { demethylase }\end{array}$ & $(81)$ \\
\hline PTC-209 & BMI1 & Polycomb ring-finger oncogene & $(82)$ \\
\hline anisomycin & lncRNA BACE1-AS & $\ln \mathrm{RNA}$ & $(125)$ \\
\hline shHOTAIR & HOTAIR & lincRNA ${ }^{* *}$ & $(126)$ \\
\hline \multicolumn{4}{|l|}{ Inhibitors } \\
\hline Birinapant & CIAP & Apoptosis resistance mediator & $(83)$ \\
\hline TG101209 & JAK2 & STAT3 signaling & $(84)$ \\
\hline CYT387 & JAK2 & STAT3 pathway & $(85)$ \\
\hline AS602801 & JNK & Signaling molecule & $(86)$ \\
\hline Macitentan & $\begin{array}{l}\text { Endothelin receptors } \\
\text { ETRA/ETRB }\end{array}$ & $\begin{array}{l}\text { Induction of ICAM on CD133+ } \\
\text { OCSCs }\end{array}$ & $(127)$ \\
\hline MK-5108 & Aurora-A kinase & $\begin{array}{l}\text { Cell cycle arrest and NFkB } \\
\text { pathway modulation }\end{array}$ & $(128)$ \\
\hline TRX-E-002-1 & c-Jun & Signaling pathway & $\begin{array}{l}(129 \\
130)\end{array}$ \\
\hline iCG-001/PRI-724 & Wnt/ $\beta$ catenin pathway & Signaling pathway & $(49)$ \\
\hline $\begin{array}{l}\text { Müllerian inhibiting substance (MIS) or the } \\
\text { MIS mimetic SP } 600125\end{array}$ & MIS RII & Receptor & $(42)$ \\
\hline Eriocalyxin B (EriB) & $\mathrm{NF \kappa B}$ & Signaling pathway & $(131)$ \\
\hline N-t-boc-Daidzein & Akt & Signaling pathway & $(132)$ \\
\hline $\begin{array}{l}\text { Tumor microenvironment-responsive } \\
\text { layer-by-layer (LbL) polymer drug carrier - } \\
\text { hyaluronan-directed targeting }\end{array}$ & $\mathrm{CD} 44$ & OCSCs receptor & $(133)$ \\
\hline $\begin{array}{l}\text { Gold nanoparticles (AuNPs) senzitisation to } \\
\text { cisplatin }\end{array}$ & EMT & Cell reprogramming process & $(134)$ \\
\hline Morpholino oligonucleotide & ABCB1 & ABC transporter & $(135)$ \\
\hline $\begin{array}{l}\text { Clostridium perfringens } \\
\text { enterotoxin (CPE) }\end{array}$ & Claudin-4 & Tight junctions receptor & $(136)$ \\
\hline \multicolumn{4}{|l|}{ Metabolic drugs } \\
\hline Lipid desaturases inhibitors & Unsaturated lipids & Lipid metabolism components & $(64)$ \\
\hline Metformin & gluconeogenesis & Glucose metabolism & $(90,91)$ \\
\hline LPAR1 inhibitors & $\begin{array}{l}\text { autotaxin-LPA-LPA } \\
\text { receptor 1-AKT1 signaling } \\
\text { axis }\end{array}$ & Lipid metabolism components & $(69)$ \\
\hline$\gamma$-secretase inhibitor (GSI) & Notch3 & CSC pathway & $(97,137)$ \\
\hline Niclosamide (antihelmintic drug) & $\begin{array}{l}\text { Disrupts metabolic } \\
\text { pathways }\end{array}$ & Signaling & $(96)$ \\
\hline Isoflavone derivative, $\mathrm{NV}-128$ & $\begin{array}{l}\text { Mithocondrial } \\
\text { bioenergetics }\end{array}$ & Apoptosis & $(138)$ \\
\hline $\begin{array}{l}\text { 2-deoxyglucose as maintenance therapy after } \\
\text { Paclitaxel }\end{array}$ & glycolysis & Metabolic pathway & $(58)$ \\
\hline \multicolumn{4}{|l|}{ Immune therapies } \\
\hline Fusions of dendritic cells and OCSC & CD44+ OCSC & OCSCs & $(139)$ \\
\hline Mab CC188 - imaging and therapy & CD133 & CSC marker & $(140)$ \\
\hline $\begin{array}{l}\text { Vaccination with OCSCs engineered to } \\
\text { express } \alpha \text {-gal epitopes }\end{array}$ & $\begin{array}{l}\mathrm{CD} 3+\mathrm{CD} 4+\mathrm{T} \text { cells } \\
\text { induction }\end{array}$ & Immune cells & $(141)$ \\
\hline $\begin{array}{l}\text { Vaccination using SKOV3 CD117(+) } \\
\text { CD44(+)CSC }\end{array}$ & NK cells activation & Immune cells & $(142)$ \\
\hline Oncolytic vaccinia virus & CXCL12/CXCR4 & $\begin{array}{l}\text { Tumor angiogenesis and } \\
\text { immunosuppressive networks }\end{array}$ & $(143)$ \\
\hline IFN alpha & SP cells & OCSCs & $(144)$ \\
\hline
\end{tabular}




\begin{tabular}{|l|l|l|l|}
\hline \multicolumn{1}{|c|}{ Proposed therapeutic agent } & \multicolumn{2}{c|}{ Target } & \multicolumn{2}{c|}{ Target molecular class } & \multicolumn{2}{c|}{ Refs } \\
\hline Antibodies/ADCs & Ephrin-A4 (EFNA4) & Developmental protein & $(108)$ \\
\hline PF-06647263 (ADC) & PTK7 & Receptor protein tyrosine kinase & $(145)$ \\
\hline ADC & CCL5 & $\begin{array}{l}\text { Mediator of endothelial } \\
\text { differentiation of OCSC }\end{array}$ & $(146)$ \\
\hline Antibodies \&-shRNA & (mem)GRP78 & $\begin{array}{l}\text { Stress-inducible endoplasmic } \\
\text { reticulum chaperone that is also } \\
\text { expressed on the plasma membrane }\end{array}$ & $(110)$ \\
\hline $\begin{array}{l}\text { Antibodies directed against the carboxy- } \\
\text { terminal domain of GRP78 }\end{array}$ & $\begin{array}{l}\text { Glycosylphosphatidylinositol- } \\
\text { anchored membrane protein, CSC } \\
\text { marker }\end{array}$ & $(147)$ \\
\hline SWA11 mAb & CD24 & $\begin{array}{l}\text { Cell-cell adhesion glycoprotein, CSC } \\
\text { marker }\end{array}$ & $(148)$ \\
\hline Monoclonal antibody A3D8 & CD44 & &
\end{tabular}

**intervening non-coding RNA

an aggressive phenotype that allows tumor relapse and drug resistance $(73,74)$. By using a systems biology approach to analyze expression profiles from 145 human serous ovarian tumors, a stem-like 51-gene signature was found to be correlated with increased risk of relapse (75). Additionally, it is emerging that even newer biologically targeted therapy might affect the survival of CSCs. For example, anti-angiogenic treatment with bevacizumab increases tumor hypoxia, which in turn induces Hif-1- $\alpha$ target genes, among which VEGFA, which can stimulate OCSCs. This positive feed-back loop allows stem cell escape and repopulation of resistant tumors (76). These observations highlight the importance of finding new modalities to target and eliminate OCSCs. Here we will discuss several new targets and therapeutic approaches recently described (see Fig. 3 and Table 2).

Epigenetic changes occur during cancer cell reprogramming as well as following cytotoxic therapy. Recent studies showed that ATG4A and HIST1H2BN genes were hypomethylated in OCSCs and their hypomethylation

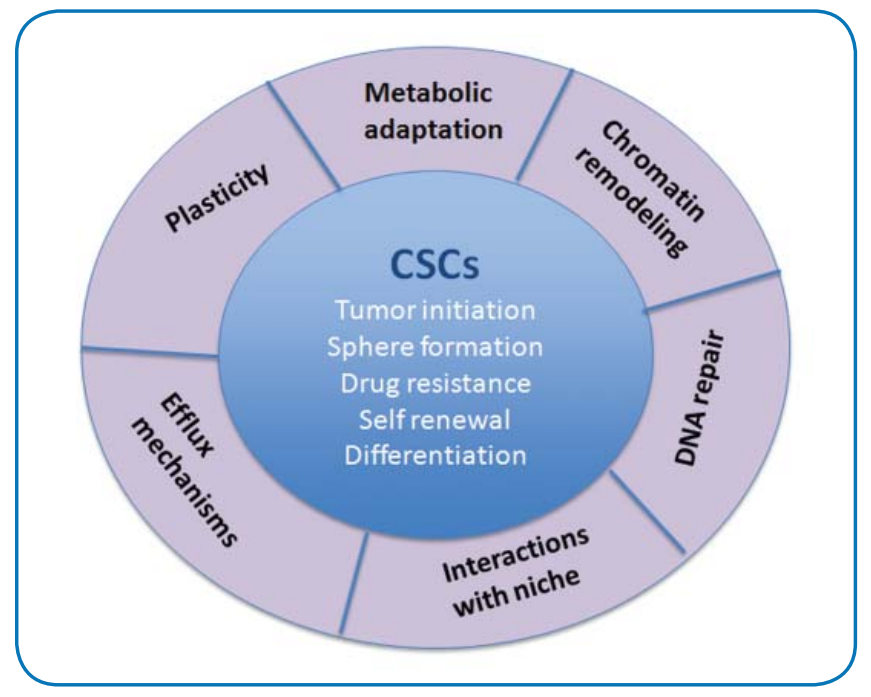

Fig. 3. - Proposed model illustrating CSCs characteristics and therapeutic vulnerabilities was correlated with poor prognosis (77). Another study showed that increased DNA methylation of a subset of genes was associated to acquired resistance to cisplatin, and the use of a demethylating agent restored sensitivity to this drug (78). Our research on the action of the novel DNA-hypomethylating agent SGI-110 (guadecitabine, Astex Pharmaceuticals Inc, see Table 2) in OC demonstrated that by inhibiting DNA methyl-transferase activity, the agent reduced the number and the tumor initiating capacity of $\mathrm{ALDH}^{+}$OC cells. SGI-110 also re-sensitized tumors to platinum therapy by allowing re-expression of differentiation genes and forcing CSCs into cellular differentiation (79). Other epigenetic modulators could also inhibit CSCs by promoting differentiation into proliferative and aggressive tumor cells.

The increased activity of a group of bromodomain and extraterminal (BET) family of proteins that recognize acetylated lysine on histones was correlated with CSC associated genes expression (c-Myc, and ALDH), and tumor formation. For example, analysis of the effects of JQ1 (Table 2), a selective BET inhibitor, in combination with cisplatin demonstrated particular effectiveness in down-regulating ALDH1A1 mRNA expression levels and inhibition of intracellular ALDH enzymatic activity (80). The decrease in ALDH1A1 expression and activity in turn significantly affected spheroids proliferation by depleting the CSCs population. Increase of histone $\mathrm{H} 3$ trimethylation at lysine $27(\mathrm{H} 3 \mathrm{~K} 27 \mathrm{me} 3)$ was correlated to differentiation of both normal and cancer stem cells. A recent study indicated that GSKJ4 (Table 2), a selective Jumonji H3K27 demethylase inhibitor, effectively targeted the CSC population derived from human A2780 OC cell lines by inducing cell death, disrupting self-renewal and tumor initiating capacity, while no toxic effects were evidenced in normal fibroblasts (81). Using PTC-209 (Table 2), a small transcription inhibitor of BMI1 - a polycomb ring-finger oncogene enriched in CSCs, Dey et al. have reported a decrease in clonal growth of OC cells and induction of autophagy-mediated 
necroptosis independent from apoptosis-mediated cell death (82). Necroptotic cell death provides an alternative strategy to target chemoresistant OCSCs that are characterized by impaired apoptotic pathways.

The expression and activity of ALDH1A1 alone or in combination with other CSC-related markers (CD133) has been linked to CSC maintenance and survival. In addition, our previous data indicated that residual tumors from platinum sensitive ovarian orthotopic xenograft models were highly enriched in CSCs positive for ALDH activity (79). This evidence led us to test a novel potent ALDH1A1 inhibitor (CM037; (ethyl-2-((4-oxo-3-(3(pryrrolidin-1-yl)propyl)-3,4-dihydrobenzo [4,5] thioeno [3,2-d]pyrimidin-2-yl)thio)acetate)) identified through high-throughput screening of the ChemDiv library (53). Treatment with CM037 (Table 2) effectively blocked ALDH1A1 activity as measured by flow cytometry, and dose response experiments demonstrated a relative decrease in OC spheroids formation as a consequence of CSC depletion. Further, in vitro studies demonstrated a sensitization of OC spheroids to platinum treatment, indicating that ALDH1A1 is a possible therapeutic target in combination with platinum treatment.

Transcriptome analyses generated accumulating evidence of specific signaling pathways enriched in CSCs in comparison with non-CSCs. One study reported upregulation of homologous recombination DNA repair and anti-apoptotic signals in CA125-negative stem-like cells (83). This subpopulation enriched in carboplatin-resistant OCSCs overcame apoptotic processes by increasing cellular inhibitor of apoptosis 1 (cIAP)mediated DNA repair mechanisms. By using birinapant (Table 2), a compound that binds to cIAP and targets it for degradation, apoptotic processes were restored and CA125-negative cells were sensitized to carboplatin leading to tumor regression in PDX mouse models. Moreover, the study increased awareness of the existence of CA125 negative OC cells as highly tumorigenic resistant stem like cells. Although carboplatin treated mice had undetectable level of CA125 immediately post chemotherapy despite the presence of residual tumors, off-treatment CA125 level were increased in carboplatin treated mice, suggesting the necessity to characterize more reliable biomarkers able to identify the residual therapy-resistant CA125-negative cell populations.

Another report showed increased stemness profile of $\mathrm{CD}_{2} 4^{+}$OC cells, which also display increased p-Stat3 activation (84). Inhibition of the upstream STAT regulator JAK2 using TG101209 (Table 2) induced preferentially the death of $\mathrm{CD} 24^{+}$cells, which in turn reduced metastases in $\mathrm{OC}$ mouse models and prolonged animal survival. Using the JAK2-specific inhibitor CYT387 (Table 2) in combination with paclitaxel, a reduction of tumor burden was observed in xenografts (85). The JAK2 inhibitor overcame the effects of paclitaxel, which by itself induced Oct4 and CD117 markers' expression in OCSCs resistant to treatment. Moreover, a newly developed ATP-competitive JNK pathway inhibitor (AS602801, Table 2) tested in phase II trial for the treatment of endometriosis was tested in OC and other cancer models, such as pancreatic cancer, non-small cell lung cancer and glioblastoma (86). When tested in mice, AS602801 was shown to interfere with CSCs self-renewal with concomitant reduction in Sox2, Nanog, and Bmi1 expression and tumor growth, thus providing the rationale for clinical development.

Metabolic pathways fueling the growth of cancer cells have been subject to active research during the last few years (87). Tumor cells display significant alterations of cellular metabolism with an increase in glucose uptake, glutamine consumption, and lipid biosynthesis. These steps are essential to provide energetic support for the increased rates of cancer cell growth, proliferation and survival. In a recent study, we identified and characterized lipid unsaturation in ovarian CSCs compared to non-CSCs by chemical imaging of single living cells using hyperspectral stimulated Raman scattering (SRS) microscopy (64). Use of lipid desaturases inhibitors (Table 2) significantly disrupted stem cell characteristics in vitro and in vivo, including inhibition of sphere formation and tumor initiation, demonstrating a critical role of lipid desaturases in maintaining the CSC population and suggesting a potential new therapeutic approach targeting OCSCs.

It is known that type 2 diabetes, associated with altered glucose metabolism, has a negative impact on the survival of OC patients (88). However, it has been reported that OC patients receiving metformin treatment for diabetes have improved outcomes as compared with those receiving other anti-glycemic drugs (89). Buckanovich's lab has tested the effect of metformin (Table 2) alone or in combination with cisplatin on $\mathrm{OC}$ both in vitro and in vivo. Results showed that use of $1 \mathrm{mM}$ metformin decreases $\mathrm{ALDH}^{+}$OCSCs population in SKOV3 and A2780 cell lines and $\mathrm{ALDH}^{+}$tumor sphere formation from cell lines or patient specimens (90). Combination of metformin and cisplatin slowed tumor growth in mice, which led to prolonged survival, as compared to animals treated with monotherapy. Even when used alone, metformin decreased tumor growth and reduced $\mathrm{ALDH}^{+}$ OCSCs in tumors. Other reports showed that when used at lower doses (0.03-0.3 mM range), metformin did not impact cell proliferation but retained its ability to reduce OCSCs population, as measured by frequency of cells harboring CD $44^{+} \mathrm{CD} 117^{+}$markers (91). It has been proposed that this metabolic modifying agent also inhibits EMT, reduces the expression of survivin, thereby potentiating the effects of cisplatin. In all, compared to other CSC markers with no clear functional roles, and widely expressed in both cancer and normal cells $(92,93)$, 
the unique signature of CSC metabolism could identify more stable stem cell markers, providing new promising approaches to target resistant CSCs.

\section{CONCLUSIONS}

Development of therapies targeting OCSCs have garnered increased interest in recent years (94). New research efforts concentrate on developing novel therapeutics targeting OCSCs ranging from high throughput screening of chemical compounds $(95,96)$ to stem cell signaling inhibitors proposed to increase sensitivity to standard cytotoxics (97).

\section{REFERENCES}

1. Cancer Stem Cells, 1st Editon. Targeting the Roots of Cancer, Seeds of Metastasis, and Sources of Therapy Resistance, Huiping Liu, Justin Lathia eds., Academic Press, Elsevier, 2016.

2. Shackleton M, Normal stem cells and cancer stem cells: similar and different, Seminars in Cancer Biology, 20, 85-92 (2010).

3. Karamboulas C, Ailles L, Developmental signaling pathways in cancer stem cells of solid tumors, Biochimica et Biophysica Acta (BBA) - General Subjects, 1830, 2481-2495 (2013).

4. Al-Hajj M, Wicha MS, Benito-Hernandez A, Morrison SJ, Clarke MF, Prospective identification of tumorigenic breast cancer cells, Proc. Natl. Acad. Sci. U.S.A., 100, 3983-3988 (2003).

5. Gupta PB, Chaffer CL, Weinberg RA, Cancer stem cells: mirage or reality? Nat. Med., 15, 1010-1012 (2009).

6. Clevers H, Cancer therapy: Defining stemness, Nature, 534, 176-177 (2016).

7. Scheel C, Weinberg RA, Phenotypic plasticity and epithelial-mesenchymal transitions in cancer and normal stem cells?

Int. J. Cancer, 129, 2310-2314 (2011).

8. Valent P, Bonnet D, De Maria R, Lapidot T, Copland M, Melo JV, et al., Cancer stem cell definitions and terminology: the devil is in the details, Nat. Rev. Cancer., 12, 767-775 (2012).

9. Quintana E, Shackleton M, Sabel MS, Fullen DR, Johnson TM, Morrison SJ. Effcient tumour formation by single human melanoma cells, Nature, 456, 593-598 (2008).

10. Kelly PN, Dakic A, Adams JM, Nutt SL, Strasser A, Tumor growth need not be driven by rare cancer stem cells, Science, 317, 337 (2007).

11. Baker M, Cancer stem cells, becoming common, (2008).

12. Shah MM, Landen CN, Ovarian cancer stem cells: are they real and why are they important? Gynecol. Oncol., 132, 483-489 (2014).

13. Telleria CM, Repopulation of ovarian cancer cells after chemotherapy, Cancer Growth Metastasis, 6, 15-21 (2013).

14. Statistics New York: Ovarian Cancer Research Fund Alliance, 2016 [updated 2016. Available from: https://ocrfa.org/patients/ about-ovarian-cancer/statistics/.

15. Lengyel E, Ovarian cancer development and metastasis, Am. J. Pathol., 177, 1053-1064 (2010).

16. Marquez RT, Baggerly KA, Patterson AP, Liu J, Broaddus R, Frumovitz M, et al., Patterns of gene expression in different histotypes of epithelial ovarian cancer correlate with those in normal fallopian tube, endometrium, and colon,

Clin. Cancer Res., 11, 6116-6126 (2005).

17. Cancer Genome Atlas Research N, Integrated genomic analyses of ovarian carcinoma, Nature, 474, 609-615 (2011).
It is anticipated that a multi-targeted approach will be more successful in eliminating treatment resistant OCSCs and improve clinical outcomes (76). After 10 years of OCSC research, the most important unanswered questions remain: 1) Do OCSCs harbor unique vulnerabilities that can be exploited to improve treatment outcomes? 2) Are non-CSCs capable of reverting to CSC phenotype under the pressure of treatment induced TME alterations? 3) Which are the most robust OCSC markers?

Acknowledgements: This work was supported by a US Department of Veterans Affairs Merit Award (to DM) and the NCI R21CA198409 to DM.

18. Szotek PP, Chang HL, Brennand K, Fujino A, Pieretti-Vanmarcke R, Lo Celso C, et al., Normal ovarian surface epithelial label-retaining cells exhibit stem/progenitor cell characteristics, Proc. Natl. Acad. Sci. U.S.A., 105, 12469-12473 (2008).

19. Bowen NJ, Walker LD, Matyunina LV, Logani S, Totten KA, Benigno BB, et al., Gene expression profiling supports the hypothesis that human ovarian surface epithelia are multipotent and capable of serving as ovarian cancer initiating cells, BMC Med. Genomics, 2, 71 (2009).

20. Dubeau L, The cell of origin of ovarian epithelial tumours, Lancet Oncol., 9, 1191-1197 (2008).

21. Zweemer RP, van Diest PJ, Verheijen RH, Ryan A, Gille JJ, Sijmons RH, et al., Molecular evidence linking primary cancer of the fallopian tube to BRCA1 germline mutations, Gynecol. Oncol., 76, 45-50 (2000).

22. McEwen AR, McConnell DT, Kenwright DN, Gaskell DJ, Cherry A, Kidd AM, Occult cancer of the fallopian tube in a BRCA2 germline mutation carrier at prophylactic salpingo-oophorectomy, Gynecol. Oncol., 92, 992-994 (2004).

23. Eckert MA, Pan S, Hernandez KM, Loth RM, Andrade J, Volchenboum SL, et al., Genomics of Ovarian Cancer Progression Reveals Diverse Metastatic Trajectories Including Intraepithelial Metastasis to the Fallopian Tube, Cancer Discov., 6, 1342-1351 (2016).

24. Hosseini H, Obradovic MM, Hoffmann M, Harper KL, Sosa MS, Werner-Klein M, et al., Early dissemination seeds metastasis in breast cancer, Nature, 2016.

25. Harper KL, Sosa MS, Entenberg D, Hosseini H, Cheung JF, Nobre R, et al., Mechanism of early dissemination and metastasis in Her2+ mammary cancer, Nature, 2016.

26. Ghajar CM, Bissell MJ, Metastasis: Pathways of parallel progression, Nature, 2016.

27. Szotek PP, Pieretti-Vanmarcke R, Masiakos PT, Dinulescu DM, Connolly D, Foster R, et al., Ovarian cancer side population defines cells with stem cell-like characteristics and Mullerian Inhibiting Substance responsiveness,

Proc. Natl. Acad. Sci. U.S.A., 103, 11154-11159 (2006).

28. Silva IA, Bai S, McLean K, Yang K, Griffith K, Thomas D, et al., Aldehyde dehydrogenase in combination with CD133 defines angiogenic ovarian cancer stem cells that portend poor patient survival, Cancer Res., 71, 3991-4001 (2011).

29. Choi YP, Shim HS, Gao MQ, Kang S, Cho NH, Molecular portraits of intratumoral heterogeneity in human ovarian cancer, Cancer Lett., 307, 62-71 (2011).

30. Stewart JM, Shaw PA, Gedye C, Bernardini MQ, Neel BG, Ailles 
LE, Phenotypic heterogeneity and instability of human ovarian tumor-initiating cells, Proc. Natl. Acad. Sci. U.S.A.,

108, 6468-6473 (2011).

31. Zeimet AG, Reimer D, Sopper S, Boesch M, Martowicz A, Roessler J, et al., Ovarian cancer stem cells,

Neoplasma, 59, 747-55 (2012).

32. Wang L, Mezencev R, Bowen NJ, Matyunina LV, McDonald JF, Isolation and characterization of stem-like cells from a human ovarian cancer cell line,

Mol. Cell Biochem., 363, 257-268 (2012).

33. Babahosseini H, Ketene AN, Schmelz EM, Roberts PC, Agah M, Biomechanical profile of cancer stem-like/tumor-initiating cells derived from a progressive ovarian cancer model,

Nanomedicine, 10, 1013-1019 (2014).

34. Sodek KL, Ringuette MJ, Brown TJ, Compact spheroid formation by ovarian cancer cells is associated with contractile behavior and an invasive phenotype, Int. J. Cancer, 124, 2060-2070 (2009).

35. Liu KC, Yo YT, Huang RL, Wang YC, Liao YP, Huang TS, et al., Ovarian cancer stem-like cells show induced translineage-differentiation capacity and are suppressed by alkaline phosphatase inhibitor, Oncotarget, 4, 2366-2382 (2013).

36. Ricci F, Bernasconi S, Perego P, Ganzinelli M, Russo G, Bono F, et al., Ovarian carcinoma tumor-initiating cells have a mesenchymal phenotype, Cell Cycle, 11, 1966-1976 (2012).

37. Jiang H, Lin X, Liu Y, Gong W, Ma X, Yu Y, et al., Transformation of epithelial ovarian cancer stemlike cells into mesenchymal lineage via EMT results in cellular heterogeneity and supports tumor engraftment, Mol. Med., 18, 1197-1208 (2012).

38. Chen X, Zhang J, Zhang Z, Li H, Cheng W, Liu J, Cancer stem cells, epithelial-mesenchymal transition, and drug resistance in high-grade ovarian serous carcinoma,

Hum. Pathol., 44, 2373-2384 (2013).

39. Steffensen KD, Alvero AB, Yang Y, Waldstrom M, Hui P, Holmberg JC, et al., Prevalence of epithelial ovarian cancer stem cells correlates with recurrence in early-stage ovarian cancer, J. Oncol., 620523 (2011).

40. Hosonuma S, Kobayashi Y, Kojo S, Wada H, Seino K, Kiguchi $\mathrm{K}$, et al., Clinical significance of side population in ovarian cancer cells, Hum. Cell, 24, 9-12 (2011).

41. Kobayashi Y, Seino K, Hosonuma S, Ohara T, Itamochi H, Isonishi S, et al., Side population is increased in paclitaxel-resistant ovarian cancer cell lines regardless of resistance to cisplatin, Gynecol. Oncol., 121, 390-394 (2011).

42. Wei X, Dombkowski D, Meirelles K, Pieretti-Vanmarcke R, Szotek PP, Chang HL, et al., Mullerian inhibiting substance preferentially inhibits stem/progenitors in human ovarian cancer cell lines compared with chemotherapeutics,

Proc. Natl. Acad. Sci. U.S.A., 107, 18874-18879 (2010).

43. Calcagno AM, Salcido CD, Gillet JP, Wu CP, Fostel JM, Mumau MD, et al., Prolonged drug selection of breast cancer cells and enrichment of cancer stem cell characteristics, J. Natl. Cancer Inst., 102, 1637-1652 (2010).

44. Hu L, McArthur C, Jaffe RB, Ovarian cancer stem-like side-population cells are tumourigenic and chemoresistant,

Br. J. Cancer, 102, 1276-1283 (2010).

45. Puiffe ML, Le Page C, Filali-Mouhim A, Zietarska M, Ouellet V, Tonin PN, et al., Characterization of ovarian cancer ascites on cell invasion, proliferation, spheroid formation, and gene expression in an in vitro model of epithelial ovarian cancer, Neoplasia, 9, 820-829 (2007).

46. Tibbitt MW, Anseth KS, Hydrogels as extracellular matrix mimics for 3D cell culture, Biotechnol. Bioeng., 103, 655-663 (2009).

47. Liang D, Ma Y, Liu J, Trope CG, Holm R, Nesland JM, et al., The hypoxic microenvironment upgrades stem-like properties of ovarian cancer cells, BMC Cancer, 12, 201 (2012).

48. Chau WK, Ip CK, Mak AS, Lai HC, Wong AS. c-Kit mediates chemoresistance and tumor-initiating capacity of ovarian cancer cells through activation of Wnt/beta-catenin-ATP-binding cassette G2 signaling, Oncogene, 32, 2767-2781 (2013).

49. Nagaraj AB, Joseph P, Kovalenko O, Singh S, Armstrong A, Redline R, et al., Critical role of Wnt/beta-catenin signaling in driving epithelial ovarian cancer platinum resistance, Oncotarget, 6, 23720-23734 (2015).

50. Yasuda K, Torigoe T, Mariya T, Asano T, Kuroda T, Matsuzaki J, et al., Fibroblasts induce expression of FGF4 in ovarian cancer stem-like cells/cancer-initiating cells and upregulate their tumor initiation capacity, Lab. Invest., 94, 1355-1369 (2014).

51. Deng X, Zhang P, Liang T, Deng S, Chen X, Zhu L, Ovarian cancer stem cells induce the M2 polarization of macrophages through the PPARgamma and NF-kappaB pathways,

Int. J. Mol. Med., 36, 449-454 (2015).

52. Cao L, Shao M, Schilder J, Guise T, Mohammad KS, Matei D, Tissue transglutaminase links TGF-beta, epithelial to mesenchymal transition and a stem cell phenotype in ovarian cancer,

Oncogene, 31, 2521-2534 (2012).

53. Condello S, Morgan CA, Nagdas S, Cao L, Turek J, Hurley TD, et al., beta-Catenin-regulated ALDH1A1 is a target in ovarian cancer spheroids, Oncogene, 34, 2297-2308 (2015).

54. Yin G, Alvero AB, Craveiro V, Holmberg JC, Fu HH, Montagna $\mathrm{MK}$, et al., Constitutive proteasomal degradation of TWIST-1 in epithelial-ovarian cancer stem cells impacts differentiation and metastatic potential, Oncogene, 32, 39-49 (2013).

55. Nuti SV, Mor G, Li P, Yin G, TWIST and ovarian cancer stem cells: implications for chemoresistance and metastasis,

Oncotarget, 5, 7260-7271 (2014).

56. Bhartiya D, Singh J, FSH-FSHR3-stem cells in ovary surface epithelium: basis for adult ovarian biology, failure, aging, and cancer, Reproduction, 149, R35-R48 (2015).

57. Belotte J, Fletcher NM, Alexis M, Morris RT, Munkarah AR, Diamond MP, et al., Sox2 gene amplification significantly impacts overall survival in serous epithelial ovarian cancer, Reprod. Sci., 22, 38-46 (2015).

58. Alvero AB, Montagna MK, Sumi NJ, Joo WD, Graham E, Mor G, Multiple blocks in the engagement of oxidative phosphorylation in putative ovarian cancer stem cells: implication for maintenance therapy with glycolysis inhibitors,

Oncotarget, 5, 8703-8715 (2014).

59. Vacanti NM, Metallo CM, Exploring metabolic pathways that contribute to the stem cell phenotype, Biochim. Biophys. Acta., 1830, 2361-2369 (2013).

60. Rafalski VA, Mancini E, Brunet A, Energy metabolism and energy-sensing pathways in mammalian embryonic and adult stem cell fate, J. Cell Sci., 125(Pt 23), 5597-5608 (2012).

61. Anderson AS, Roberts PC, Frisard MI, Hulver MW, Schmelz EM, Ovarian tumor-initiating cells display a flexible metabolism, Exp. Cell Res., 328, 44-57 (2014).

62. Vermeersch KA, Wang L, Mezencev R, McDonald JF, Styczynski MP, OVCAR-3 spheroid-derived cells display distinct metabolic profiles, PLoS One, 10, e0118262 (2015).

63. Vermeersch KA, Wang L, McDonald JF, Styczynski MP, Distinct metabolic responses of an ovarian cancer stem cell line, BMC Syst. Biol., 8, 134 (2014).

64. Li J, Condello S, Thomes-Pepin J, Ma X, Xia Y, Hurley TD, et al., Lipid Desaturation Is a Metabolic Marker and Therapeutic Target of Ovarian Cancer Stem Cells. Cell Stem Cell, 20, 303-14 e5 (2017).

65. Weber JM, Metabolic fuels: regulating fluxes to select mix, J. Exp. Biol., 214(Pt 2), 286-294 (2011).

66. Pascual G, Avgustinova A, Mejetta S, Martin M, Castellanos A, Attolini CS, et al., Targeting metastasis-initiating cells through the fatty acid receptor CD36, Nature, 541, 41-45 (2017).

67. Pavlovic M, Arnal-Estape A, Rojo F, Bellmunt A, Tarragona M, Guiu M, et al., Enhanced MAF Oncogene Expression and Breast Cancer Bone Metastasis, J. Natl. Cancer Inst.,12, djv256 (2015). 
68. Cardenas C, Montagna MK, Pitruzzello M, Lima E, Mor G, Alvero AB, Adipocyte microenvironment promotes Bclxl expression and confers chemoresistance in ovarian cancer cells, Apoptosis, 22, 558-569 (2017).

69. Seo EJ, Kwon YW, Jang IH, Kim DK, Lee SI, Choi EJ, et al., Autotaxin Regulates Maintenance of Ovarian Cancer Stem Cells through Lysophosphatidic Acid-Mediated Autocrine Mechanism, Stem Cells, 34, 551-564 (2016).

70. Guddati AK, Ovarian cancer stem cells: elusive targets for chemotherapy, Med. Oncol., 29, 3400-3408 (2012).

71. Hennessy BT, Coleman RL, Markman M, Ovarian cancer, Lancet, 374, 1371-1382 (2009).

72. Kurman RJ, Shih Ie M, The origin and pathogenesis of epithelial ovarian cancer: a proposed unifying theory,

Am. J. Surg. Pathol., 34, 433-443 (2010)

73. Craveiro V, Yang-Hartwich Y, Holmberg JC, Joo WD, Sumi NJ, Pizzonia J, et al., Phenotypic modifications in ovarian cancer stem cells following Paclitaxel treatment,

Cancer Med., 2, 751-762 (2013).

74. Kulkarni-Datar K, Orsulic S, Foster R, Rueda BR, Ovarian tumor initiating cell populations persist following paclitaxel and carboplatin chemotherapy treatment in vivo,

Cancer Lett., 339, 237-246 (2013).

75. Schwede M, Spentzos D, Bentink S, Hofmann O, Haibe-Kains B, Harrington D, et al., Stem cell-like gene expression in ovarian cancer predicts type II subtype and prognosis, PLoS One, 8, e57799 (2013).

76. Jang K, Kim M, Gilbert CA, Simpkins F, Ince TA, Slingerland $J M, V E G F A$ activates an epigenetic pathway upregulating ovarian cancer-initiating cells, EMBO Mol. Med., 9, 304-318 (2017).

77. Liao YP, Chen LY, Huang RL, Su PH, Chan MW, Chang CC, et al., Hypomethylation signature of tumor-initiating cells predicts poor prognosis of ovarian cancer patients, Hum. Mol. Genet., 23, 1894-1906 (2014).

78. Zeller C, Dai W, Steele NL, Siddiq A, Walley AJ, Wilhelm-Benartzi CS, et al., Candidate DNA methylation drivers of acquired cisplatin resistance in ovarian cancer identified by methylome and expression profiling,

Oncogene, 31, 4567-4576 (2012).

79. Wang Y, Cardenas H, Fang F, Condello S, Taverna P, Segar M, et al., Epigenetic targeting of ovarian cancer stem cells, Cancer Res., 74, $4922-4936$ (2014).

80. Yokoyama Y, Zhu H, Lee JH, Kossenkov AV, Wu SY, Wickramasinghe JM, et al., BET Inhibitors Suppress ALDH Activity by Targeting ALDH1A1 Super-Enhancer in Ovarian Cancer, Cancer Res., 76, 6320-6330 (2016).

81. Sakaki H, Okada M, Kuramoto K, Takeda H, Watarai H, Suzuki S, et al., GSKJ4, A Selective Jumonji H3K27 Demethylase Inhibitor, Effectively Targets Ovarian Cancer Stem Cells,

Anticancer Res., 35, 6607-6614 (2015).

82. Dey A, Mustafi SB, Saha S, Kumar Dhar Dwivedi S, Mukherjee P, Bhattacharya R, Inhibition of BMI1 induces autophagy-mediated necroptosis, Autophagy, 12, 659-670 (2016).

83. Janzen DM, Tiourin E, Salehi JA, Paik DY, Lu J, Pellegrini M, et al. An apoptosis-enhancing drug overcomes platinum resistance in a tumour-initiating subpopulation of ovarian cancer, Nat. Commun., 6, 7956 (2015).

84. Burgos-Ojeda D, Wu R, McLean K, Chen YC, Talpaz M, Yoon E, et al., CD24+ Ovarian Cancer Cells Are Enriched for Cancer-Initiating Cells and Dependent on JAK2 Signaling for Growth and Metastasis, Mol. Cancer Ther., 14, 1717-1727 (2015)

85. Abubaker K, Luwor RB, Escalona R, McNally O, Quinn MA, Thompson EW, et al., Targeted Disruption of the JAK2/STAT3 Pathway in Combination with Systemic Administration of Paclitaxel Inhibits the Priming of Ovarian Cancer Stem Cells Leading to a Reduced Tumor Burden, Front Oncol., 4, 75 (2014).
86. Okada M, Kuramoto K, Takeda H, Watarai H, Sakaki H, Seino S, et al., The novel JNK inhibitor AS602801 inhibits cancer stem cells in vitro and in vivo, Oncotarget, 19, 27021-27032 (2016).

87. Boroughs LK, DeBerardinis RJ, Metabolic pathways promoting cancer cell survival and growth,

Nat. Cell Biol., 4, 351-359 (2015).

88. Bakhru A, Buckanovich RJ, Griggs JJ, The impact of diabetes on survival in women with ovarian cancer,

Gynecol. Oncol., 1, 106-111 (2011).

89. Bodmer M, Becker C, Meier C, Jick SS, Meier CR, Use of metformin and the risk of ovarian cancer: a case-control analysis, Gynecol. Oncol., 2, 200-204 (2011).

90. Shank JJ, Yang K, Ghannam J, Cabrera L, Johnston CJ, Reynolds RK, et al., Metformin targets ovarian cancer stem cells in vitro and in vivo, Gynecol. Oncol., 2, 390-397 (2012).

91. Zhang R, Zhang P, Wang H, Hou D, Li W, Xiao G, et al., Inhibitory effects of metformin at low concentration on epithelial-mesenchymal transition of CD44(+)CD117(+) ovarian cancer stem cells, Stem Cell Res. Ther., 6, 262 (2015).

92. Clevers H, The cancer stem cell: premises, promises and challenges, Nat. Med., 3, 313-319 (2011).

93. Visvader JE, Lindeman GJ, Cancer stem cells in solid tumours: accumulating evidence and unresolved questions, Nat. Rev. Cancer., 10, 755-768 (2008).

94. Walters Haygood CL, Arend RC, Straughn JM, Buchsbaum DJ, Ovarian cancer stem cells: Can targeted therapy lead to improved progression-free survival? World J. Stem Cells, 4, 441-447 (2014).

95. Mezencev R, Wang L, McDonald JF, Identification of inhibitors of ovarian cancer stem-like cells by high-throughput screening, J. Ovarian Res., 1, 30 (2012).

96. Yo YT, Lin YW, Wang YC, Balch C, Huang RL, Chan MW, et al., Growth inhibition of ovarian tumor-initiating cells by niclosamide, Mol. Cancer Ther., 8, 1703-1712 (2012).

97. McAuliffe SM, Morgan SL, Wyant GA, Tran LT, Muto KW, Chen YS, et al., Targeting Notch, a key pathway for ovarian cancer stem cells, sensitizes tumors to platinum therapy,

Proc. Natl. Acad. Sci. U.S.A., 43, E2939-E2948 (2012).

98. Gao Q, Geng L, Kvalheim G, Gaudernack G, Suo Z, Identification of cancer stem-like side population cells in ovarian cancer cell line OVCAR-3, Ultrastruct. Pathol., 4, 175-181 (2009).

99. Ruan Z, Liu J, Kuang Y, Isolation and characterization of side population cells from the human ovarian cancer cell line $S K-O V-3$, Exp. Ther. Med., 6, 2071-2018 (2015).

100. Wei Z, Lv S, Wang Y, Sun M, Chi G, Guo J, et al., Biological characteristics of side population cells in a self-established human ovarian cancer cell line, Oncol. Lett., 1, 41-48 (2016).

101. Dou J, Jiang C, Wang J, Zhang X, Zhao F, Hu W, et al., Using ABCG2-molecule-expressing side population cells to identify cancer stem-like cells in a human ovarian cell line,

Cell Biol. Int., 3, 227-234 (2011).

102. Boesch M, Zeimet AG, Reimer D, Schmidt S, Gastl G, Parson $\mathrm{W}$, et al., The side population of ovarian cancer cells defines a heterogeneous compartment exhibiting stem cell characteristics, Oncotarget., 16, 7027-7039 (2014).

103. Wang YC, Yo YT, Lee HY, Liao YP, Chao TK, Su PH, et al., ALDH1-bright epithelial ovarian cancer cells are associated with CD44 expression, drug resistance, and poor clinical outcome, Am. J. Pathol., 3, 1159-1169 (2012).

104.Kuroda T, Hirohashi Y, Torigoe T, Yasuda K, Takahashi A, Asanuma $\mathrm{H}$, et al., ALDH1-high ovarian cancer stem-like cells can be isolated from serous and clear cell adenocarcinoma cells, and ALDH1 high expression is associated with poor prognosis, PLoS One, 6, e65158 (2013).

105.Mizuno T, Suzuki N, Makino H, Furui T, Morii E, Aoki H, et al., Cancer stem-like cells of ovarian clear cell carcinoma are enriched in the ALDH-high population associated with an 
accelerated scavenging system in reactive oxygen species, Gynecol. Oncol., 2, 299-305 (2015).

106. Baba T, Convery PA, Matsumura N, Whitaker RS, Kondoh E, Perry T, et al., Epigenetic regulation of CD133 and tumorigenicity of CD133+ ovarian cancer cells, Oncogene., 2, 209-218 (2008).

107.Tjhay F, Motohara T, Tayama S, Narantuya D, Fujimoto K, Guo $\mathrm{J}$, et al., CD44 variant 6 is correlated with peritoneal dissemination and poor prognosis in patients with advanced epithelial ovarian cancer, Cancer Sci., 10, 1421-1428 (2015).

108.Damelin M, Bankovich A, Park A, Aguilar J, Anderson W, Santaguida M, et al., Anti-EFNA4 Calicheamicin Conjugates Effectively Target Triple-Negative Breast and Ovarian Tumor-Initiating Cells to Result in Sustained Tumor Regressions,

Clin. Cancer Res., 18, 4165-4173 (2015).

109.Zhang S, Cui B, Lai H, Liu G, Ghia EM, Widhopf GF, 2nd, et al., Ovarian cancer stem cells express ROR1, which can be targeted for anti-cancer-stem-cell therapy, Proc. Natl. Acad. Sci. U.S.A., 48, 17266-17271 (2014).

110.Mo L, Bachelder RE, Kennedy M, Chen PH, Chi JT, Berchuck A, et al., Syngeneic Murine Ovarian Cancer Model Reveals That Ascites Enriches for Ovarian Cancer Stem-Like Cells Expressing Membrane GRP78, Mol. Cancer Ther., 3, 747-756 (2015).

111.Zhang S, Balch C, Chan MW, Lai HC, Matei D, Schilder JM, et al., Identification and characterization of ovarian cancer-initiating cells from primary human tumors, Cancer Res. 68, 4311-4320 (2008).

112.Lee YJ, Wu CC, Li JW, Ou CC, Hsu SC, Tseng HH, et al., A rational approach for cancer stem-like cell isolation and characterization using CD44 and prominin-1(CD133) as selection markers, Oncotarget, 7, 78499-515 (2016).

113.Liu M, Mor G, Cheng H, Xiang X, Hui P, Rutherford T, et al., High frequency of putative ovarian cancer stem cells with CD44/CK19 coexpression is associated with decreased progression-free intervals in patients with recurrent epithelial ovarian cancer, Reprod. Sci., 20, 605-615 (2013).

114.Chung WM, Chang WC, Chen L, Lin TY, Chen LC, Hung YC, et al., Ligand-independent androgen receptors promote ovarian teratocarcinoma cell growth by stimulating self-renewal of cancer stem/progenitor cells, Stem Cell Res., 13, 24-35 (2014).

115.Zhang H, Yang Y, Wang Y, Gao X, Wang W, Liu H, et al., Relationship of tumor marker CA125 and ovarian tumor stem cells: preliminary identification, J. Ovarian Res., 8, 19 (2015).

116.Martinez-Serrano MJ, Caballero-Banos M, Vilella R, Vidal L, Pahisa J, Martinez-Roman S, Is sphere assay useful for the identification of cancer initiating cells of the ovary?, Int. J. Gynecol. Cancer, 25, 12-17 (2015).

117. Wei Z, Liu Y, Wang Y, Zhang Y, Luo Q, Man X, et al., Downregulation of Foxo3 and TRIM31 by miR-551b in side population promotes cell proliferation, invasion, and drug resistance of ovarian cancer, Med. Oncol., 33, 126 (2016).

118.Kim KH, Kang YJ, Jo JO, Ock MS, Moon SH, Suh DS, et al., DDX4 (DEAD box polypeptide 4) colocalizes with cancer stem cell marker CD133 in ovarian cancers, Biochem. Biophys. Res. Commun., 447, 315-322 (2014).

119.Alvero AB, Chen R, Fu HH, Montagna M, Schwartz PE, Rutherford T, et al., Molecular phenotyping of human ovarian cancer stem cells unravels the mechanisms for repair and chemoresistance, Cell Cycle, 8, 158-166 (2009).

120.Kryczek I, Liu S, Roh M, Vatan L, Szeliga W, Wei S, et al., Expression of aldehyde dehydrogenase and CD133 defines ovarian cancer stem cells, Int. J. Cancer, 130, 29-39 (2012).

121. Ishiguro T, Sato A, Ohata H, Ikarashi Y, Takahashi RU, Ochiya T, et al., Establishment and Characterization of an In Vitro Model of Ovarian Cancer Stem-like Cells with an Enhanced Proliferative Capacity, Cancer Res., 76, 150-160 (2016).

122. Yasuda K, Torigoe T, Morita R, Kuroda T, Takahashi A, Matsuzaki J, et al., Ovarian cancer stem cells are enriched in side population and aldehyde dehydrogenase bright overlapping population, PLoS One, 8, e68187 (2013).

123.Ji YI, Lee BY, Kang YJ, Jo JO, Lee SH, Kim HY, et al., Expression patterns of Thymosin beta 4 and cancer stem cell marker CD133 in ovarian cancers, Pathol. Oncol. Res., 19, 237-245 (2013).

124.Virant-Klun I, Stimpfel M. Novel population of small tumour-initiating stem cells in the ovaries of women with borderline ovarian cancer, Sci. Rep., 6, 34730 (2016).

125.Chen Q, Liu X, Xu L, Wang Y, Wang S, Li Q, et al., Long non-coding RNA BACE1-AS is a novel target for anisomycin-mediated suppression of ovarian cancer stem cell proliferation and invasion, Oncol. Rep., 35, 1916-1924 (2016).

126. Wang J, Chen D, He X, Zhang Y, Shi F, Wu D, et al., Downregulated lincRNA HOTAIR expression in ovarian cancer stem cells decreases its tumorgeniesis and metastasis by inhibiting epithelial-mesenchymal transition,

Cancer Cell Int., 15, 24 (2015).

127.Coffman L, Mooney C, Lim J, Bai S, Silva I, Gong Y, et al., Endothelin receptor- $A$ is required for the recruitment of antitumor $T$ cells and modulates chemotherapy induction of cancer stem cells, Cancer Biol. Ther, 14, 184-192 (2013).

128. Chefetz I, Holmberg JC, Alvero AB, Visintin I, Mor G, Inhibition of Aurora-A kinase induces cell cycle arrest in epithelial ovarian cancer stem cells by affecting NFkB pathway, Cell Cycle, 10, 2206-2214 (2011).

129. Alvero AB, Heaton A, Lima E, Pitruzzello M, Sumi N, YangHartwich Y, et al., TRX-E-002-1 Induces c-Jun-Dependent Apoptosis in Ovarian Cancer Stem Cells and Prevents Recurrence In Vivo, Mol. Cancer Ther., 15, 1279-1290 (2016).

130.Saif MW, Heaton A, Lilischkis K, Garner J, Brown DM, Pharmacology and toxicology of the novel investigational agent Cantrixil (TRX-E-002-1), Cancer Chemother. Pharmacol., 79, 303-314 (2017).

131.Leizer AL, Alvero AB, Fu HH, Holmberg JC, Cheng YC, Silasi $\mathrm{DA}$, et al., Regulation of inflammation by the NF-kappaB pathway in ovarian cancer stem cells, Am. J. Reprod. Immunol., 65, 438-447 (2011).

132.Green JM, Alvero AB, Kohen F, Mor G, 7-(O)-Carboxymethyl daidzein conjugated to $N$-t-Boc-hexylenediamine: a novel compound capable of inducing cell death in epithelial ovarian cancer stem cells, Cancer Biol. Ther., 8, 1747-1453 (2009).

133. Dreaden EC, Morton SW, Shopsowitz KE, Choi JH, Deng ZJ, Cho NJ, et al., Bimodal tumor-targeting from microenvironment responsive hyaluronan layer-by-layer ( $L b L)$ nanoparticles, ACS Nano., 8, 8374-8832 (2014).

134.Xiong X, Arvizo RR, Saha S, Robertson DJ, McMeekin S, Bhattacharya R, et al., Sensitization of ovarian cancer cells to cisplatin by gold nanoparticles, Oncotarget, 5, 6453-6465 (2014).

135.Eyre R, Harvey I, Stemke-Hale K, Lennard TW, Tyson-Capper $\mathrm{A}$, Meeson AP, Reversing paclitaxel resistance in ovarian cancer cells via inhibition of the $A B C B 1$ expressing side population, Tumour Biol., 35, 9879-9892 (2014).

136. Casagrande F, Cocco E, Bellone S, Richter CE, Bellone M, Todeschini P, et al., Eradication of chemotherapy-resistant CD44+ human ovarian cancer stem cells in mice by intraperitoneal administration of Clostridium perfringens enterotoxin, Cancer, 117, 5519-5528 (2011).

137.Vathipadiekal V, Saxena D, Mok SC, Hauschka PV, Ozbun L, Birrer MJ, Identification of a potential ovarian cancer stem cell gene expression profile from advanced stage papillary serous ovarian cancer, PLoS One, 7, e29079 (2012).

138. Alvero AB, Montagna MK, Holmberg JC, Craveiro V, Brown D, Mor G, Targeting the mitochondria activates two independent cell death pathways in ovarian cancer stem cells,

Mol. Cancer Ther., 10, 1385-1393 (2011).

139. Weng D, Song B, Durfee J, Sugiyama V, Wu Z, Koido S, et al., Induction of cytotoxic $T$ lymphocytes against ovarian cancer-initiat- 
ing cells, Int. J. Cancer, 129, 1990-2001 (2011).

140.Xu M, Rettig MP, Sudlow G, Wang B, Akers WJ, Cao D, et al. Preclinical evaluation of Mab CC188 for ovarian cancer imaging, Int. J. Cancer, 131, 1351-1359 (2012).

141.Yao X, Dong Z, Zhang Q, Wang Q, Lai D, Epithelial ovarian cancer stem-like cells expressing alpha-gal epitopes increase the immunogenicity of tumor associated antigens,

BMC Cancer, 15, 956 (2015).

142. Wu D, Wang J, Cai Y, Ren M, Zhang Y, Shi F, et al., Effect of targeted ovarian cancer immunotherapy using ovarian cancer stem cell vaccine, J. Ovarian Res., 8, 68 (2015).

143.Gil M, Komorowski MP, Seshadri M, Rokita H, McGray AJ, Opyrchal M, et al., CXCL12/CXCR4 blockade by oncolytic virotherapy inhibits ovarian cancer growth by decreasing immunosuppression and targeting cancer-initiating cells, J. Immunol., 193, 5327-5337 (2014).

144. Moserle L, Indraccolo S, Ghisi M, Frasson C, Fortunato E, Canevari S, et al., The side population of ovarian cancer cells is a primary target of IFN-alpha antitumor effects,
Cancer Res., 68, 5658-5668 (2008).

145.Damelin M, Bankovich A, Bernstein J, Lucas J, Chen L, Williams S, et al., A PTK7-targeted antibody-drug conjugate reduces tumor-initiating cells and induces sustained tumor regressions, Sci. Transl. Med., 9, 372 (2017).

146.Tang S, Xiang T, Huang S, Zhou J, Wang Z, Xie R, et al., Ovarian cancer stem-like cells differentiate into endothelial cells and participate in tumor angiogenesis through autocrine CCL5 signaling, Cancer Lett., 376, 137-147 (2016).

147.Salnikov AV, Bretz NP, Perne C, Hazin J, Keller S, Fogel M, et al., Antibody targeting of CD24 efficiently retards growth and influences cytokine milieu in experimental carcinomas, Br. J. Cancer, 108, 1449-1459 (2013).

148.Du YR, Chen Y, Gao Y, Niu XL, Li YJ, Deng WM, Effects and mechanisms of anti-CD44 monoclonal antibody A3D8 on proliferation and apoptosis of sphere-forming cells with stemness from human ovarian cancer, Int. J. Gynecol. Cancer, 23, 1367-1375 (2013). 